\title{
THE EFFECT OF COMPENSATION AND COMPETENCE ON PERFORMANCE WITH MOTIVATION AS A VARIABLE INTERVENING AN EMPLOYEE IN PARTNERS OF THE CENTRAL STATISTICS AGENCY, LUBUKLINGGAU CITY, SOUTH SUMATRA, INDONESIA
}

\author{
Yohanes Susanto ${ }^{1}$, Jefirstson Richset Riwukore ${ }^{2 *}$, \\ Farid Oktovianus ${ }^{2}$, Fellyanus Habaora ${ }^{3}$ \\ University of Bina Insan, Lubuklinggau, South Sumatra, Indonesia ${ }^{1}$ \\ University of Indo Global Mandiri, Palembang, South Sumatra, Indonesia ${ }^{2}$ \\ Bogor Agricultural University, Bogor, West Java, Indonesia ${ }^{3}$
}

\begin{abstract}
The purpose of this research was to determine the effect of compensation and competence on performance with motivation as a variable intervening an employee. The research has been conducted for 6 months, namely June to December 2019 at the Central Bureau of Statistics of Kota Lubuklinggau, South Sumatra Province, Indonesia. The population in this research were 133 respondents. This research is an explanatory research using primary data and secondary data. Primary data collection methods used interview techniques and questionnaires, in addition to conducting field observations. Secondary data were collected using documentation techniques. The data analysis uses the statistical analysis of the Structural Equation Model (SEM) based on predetermined hypotheses including compensation, competence, and motivation which partially or jointly affect the performance of partners at the Central Bureau of Statistics Office in Kota Lubuklinggau. The results showed that the aspects of compensation and competence at the Office of the Central Bureau of Statistics in Kota Lubuklinggau have not been fulfilled optimally. Partially, there is a positive and significant relationship between compensation toward motivation, competence toward performance, compensation and competence toward performance, but there is no positive and significant effect between compensation toward performance, motivation toward performance, as well as compensation-competence-motivation together toward performance, and there is also a positive but not significant influence between competence toward motivation. The results of this research indicate that there needs to
\end{abstract}

*Corresponding Author.

e-mail: jefritson@uigm.ac.id 
be an improvement in competence and compensation from the Office of the Central Bureau of Statistics of Kota Lubuklinggau to its partners.

Keywords: compensation, competence, motivation, performance

\section{INTRODUCTION}

Human resource is the individuals who work in an organization/company which is commonly known as labor, workers, employees, etc. Susiawan and Muhid (2015) stated that human resource is the most important asset in an organization, both large and small organizations, because it is a source that drives and directs organizations and maintains and develops organizations in various demands of society and times. Riwukore (2010) stated that human resource has an important role in determining the success of an organization/company to face challenges in the era of globalization, such as an expanding market and the competitiveness of human resource in the global market. This also causes human resource management to be properly organized and managed to achieve the expected performance or the set organizational goals. According to Almasri (2016), human resource management is the process of planning, organizing, directing, and controlling labor procurement, development, compensation, integration, maintenance, and termination of employment with human resource to goals of achieve individual, organization, and community. One of the operational functions of human resource management is to assess employee performance, namely the work results of employees as a whole or during a certain period in quality and quantity based on predetermined and agreed upon criteria (Sari \& Hadijah, 2016). One of the factors that greatly affects employee performance improvement is work motivation. Zamzam et al. (2018:211) explained that the activities carried out by someone as a motivation or attitude for someone to do something are always associated with motivation, the attraction of the external environment that causes a person to do or not do.

The Central Statistics Agency (BPS) is a non-ministerial institution that is responsible to the President. The main task of BPS is to provide statistical data that can be easily accessed by anyone, both government and society. To prepare data, BPS requires coordination with the Regional Government through the BPS offices in the regions. One of them is the Office of BPS of Kota Lubuklinggau 
in South Sumatra Province. Currently, the implementation of the BPS Office activities involves field officers recruited operationally with certain qualifications who are called partners. Achieving the organizational goals of BPS does not only depend on the latest technology and adequate infrastructure, but more on the human resource factor who carries out the objectives and work of the BPS organization. BPS offices that involve partners as field officers must pay more attention to the quality of partners. A quality partner is a partner who is able to carry out their duties and provide maximum output of work performance.

Partners who have high performance are oriented towards a positive attitude in their work, while those who are not satisfied show more negative attitudes towards their work. These attitudes affect the achievement of organizational goals and whether or not the agency's performance is good. The factors that influence partner quality are motivation, compensation, and competence according to the rules and their consequences. Fauziah et al. (2016) reported that motivation, competence, and compensation have a significant relationship and influence on improving human resource performance, because basically the main objective of every organization in designing a compensation system is to motivate employees in order to improve performance and retain competent employees to stay in the organization/company. According to Hasibuan (2014), compensation is all income in the form of money, materials of both direct and indirect form, received by employees in return for services provided to the company/organization. The definition of motivation according to George (2013) is effort so that someone can complete work with enthusiasm, because he wants to do it. With compensation, the organization is expected to improve employee performance or motivation to help achieve organizational goals. Furthermore, competence is a set of capabilities that are oriented towards planning and action in achieving high achievement (performance), serving, leading, managing, thinking, and being adult attitude to produce of performance achievement of effective, efficient and economical.

Habaora (2015) stated that to improve performance, motivation encourages to improve work methods based on competence as an effort to improve performance and accept consequences in the form of compensation, means to improve the performance of someone who is motivated based on competence and compensation to achieve work goals. Danila \& Riwukore (2019) stated that 
in principle, a person's performance is determined by the level of ability (competence) which is based on motivation and the consequences of work results in the form of compensation. Thus a person's motivation can have a direct effect on performance because they are able to show reliable performance which is often called intervening motivation. For this, it is necessary to do in-depth research related to motivation as an intervening variable on the performance of BPS partners with its locus at the BPS Office of Kota Lubuklinggau, South Sumatra Province, Indonesia.

\section{LITERATURE REVIEW}

\subsection{Performance}

Mulyadi (2015: 109) stated that performance (achievement) is a result of work achieved by an individual in carrying out his duties which are assigned to him based on skills, experience, and sincerity. According to Wibowo (2015: 2), performance is a series of employee behavior values that contribute, both positively and negatively to the completion of organizational goals. Performance can also be understood as a process that is referred to and measured over a certain period based on predetermined terms or agreements (Edison, 2016:190). Irham (2016: 226) stated that work results that have a strong relationship with organizational strategic objectives, community satisfaction and economic contribution can be interpreted as performance. Kasmir (2016: 182) stated the same thing, that performance is the result of work and behavior that has been achieved in completing the tasks and responsibilities given in a certain period. Performance itself can also be understood as the result of a process that directs and is measured over a certain period of time in accordance with predetermined terms and agreements. Thus, performance in human resource can be defined as work performance or output, both the quality and quantity produced by individuals within a certain time in carrying out their work in accordance with the responsibilities obtained. In an organization, it cannot be denied that the quality factor of performance management has an effect as a driven force which is able to accelerate in that direction. Good quality performance cannot be obtained by just turning the palm of the hand but it must be done with hard work and high discipline, both in the short and long term. 


\subsection{Competence}

Busro (2018: 25) stated competence is knowledge of how to do work effectively. Sutrisno (2017: 203) stated that competence is a basic characteristic of a person that enables him to provide superior performance in a particular job, role, or situation. Etymologically, the word competence comes from English competence which means well qualified or capability, and in Indonesian, it can be translated into qualified or capable (Nuryani, 2018). Palan (2003: 15) stated that competence is a set of knowledge, skills, and behaviors that must be possessed, moved, and controlled by employees or executors in a professional manner. Thus competence can be understood as a skill or expertise. The definition of competence according to the Head of the State Civil Apparatus Agency (BKN) Number 46A of 2003 is the ability or characteristics possessed by a state civil apparatus in the form of knowledge, skills, and behavioral attitudes needed in carrying out their duties so that civil apparatus can carry out their duties professionally, effectively and efficiently. Law Number 13 of 2013 concerning Manpower Article 1 paragraph (10) confirms that competence is the work ability of each individual which includes aspects of knowledge, skills, and work attitudes in accordance with established standards. Riwukore (2010) stated that competence is a standard requirement that must be met by individuals in order to be able to carry out their main tasks and functions appropriately. In other words, competence includes a number of attributes inherent in individuals, namely in the form of a combination of knowledge, skills and behavior as a means that can be used to improve performance. Based on the variety of opinions regarding the definition of competency, it can be concluded that competence is the ability to carry out a task or job based on knowledge, skills, and is supported by the attitudes that characterize the individual. This is same from that stated by Wijayanto et al. (2018) stated that competence is an underlying characteristic that includes at least five types of competency characteristics, namely motives, attitudes, self-concept, knowledge and skills.

\subsection{Motivation}

Motivation is the willingness to issue a high level toward organizational goals conditioned by the ability of that effort to fulfill individual needs 
(Sedarmayanti, 2017). Motivation can be understood as a force that strengthens behavior, provides direction for action, and a trigger to keep trying. Hasibuan (2014: 143) stated that motivation is the give of a driving force that creates a person's work enthusiasm so that they are willing to work together, work effectively, and are integrated with all efforts to achieve satisfaction. Sutrisno (2017: 110) explains that motivation is a factor that encourages someone to do certain activities. Motivation is one of the determining factors in shaping the attitude and behavior of every individual in an organization/company. Etymologically, the word motivation comes from the Latin word "movere" or is interpreted as "impulse or driving force", so that motivation can be interpreted as providing the driving force that creates the excitement of a person's work, so that they are willing to work together, work effectively and are integrated with all efforts to achieve satisfaction (Hasibuan, 2003:92). Luthans (1997:19) stated that work motivation is an attempt to get additional income or psychological incentives to cover insufficient needs. Riwukore (2010: 62) asserts that motivation is a strong force (impulse) from oneself to carry out an activity. Thus motivation can be interpreted as a driving force from within an individual who is influenced by external (environmental) factors so that a person decides to do or not do something. Zamzam et al. (2018: 211) explains that activities carried out by someone as a motivation or attitude for someone to do something are always connected with motivation, the attraction of the external environment that causes someone to do or not do something. This is to confirm the definition of motivation put forward by Armstrong (2014) that underlies someone is motivated to do something individually is the desire to have something. The same thing was also stated by Danila and Riwukore (2019: 42) that motivation is a condition that moves employees who are directed to achieve organizational goals (work goals). Motivation is formed from an employee's attitude that he must be mentally and physically ready to understand the main goals and work targets to be achieved. Riwukore and Habaora (2019: 5) say that a person's motivation in doing business is determined by economic, social, and entertainment motives. Riwukore and Habaora (2018: 95) explain that economic motivation is oriented towards income value, social motivation is oriented towards the desire to improve community social status, and hobbies motivation is oriented towards enthusiasm or desire and hobbies or to fill spare time. Habaora (2020: 10-11) 
stated that high motivation refers to economic motivation, moderate motivation refers to social motivation, and low motivation refers to entertainment motivation. Thus individual motivation consists of three stages, namely: (1) a stimulating state in an organization that arises because of bodily needs, environmental stimuli, or mental events such as thinking and memory; (2) behavior that is generated and directed by the circumstances that encourage and exist in the organization; and (3) the goals that are the direction of the behavior. Thus every behavior is based on certain motivations and each individual behavior is strongly influenced by the characteristics of the himself. Tsani F (2013: 16-17) stated that motivational and hygiene driving factors are motivational factors such as one's job, success achieved, growth opportunities, advancement in career and recognition of others, while hygiene (maintenance) includes a person's status in the organization, the relationship between an employee and his superior, the relationship between a person and his fellow workers, supervisory techniques applied by supervisors, organizational policies, administrative systems in the organization, working conditions and the applicable reward system.

\subsection{COMPENSATION}

Compensation is a broad term related to financial rewards (financial review) received by people through their employment relationship with an organization (Afifuddin, 2017:154). Wibowo (2015: 289) argued that compensation is what workers receive in exchange for their contribution to the organization. Compensation is calculated based on job evaluation, the calculation of compensation based on job evaluation is intended to obtain compensation that is close to worth and equity or in other words compensation is an activity of providing remuneration to employees. Sari and Touana (2017) stated that by creating a good and healthy organizational condition and maintaining employee commitment, employee satisfaction is an important aspect of the organization and compensation has an important meaning because compensation reflects the organization's efforts to maintain and improve the welfare of employees. Furthermore, it was reported that experience shows that inadequate compensation can reduce work performance, work motivation, and employee job satisfaction, and can even cause potential employees to leave the organization. According to Yani (2012), 
the objectives of effective compensation management are to obtain quality personnel, retain existing employees, ensure fairness, respect for desired behavior, control costs, follow legal rules, facilitate understanding, and improve administrative efficiency. The essence of compensation according to Handoko (2011) is anything that employees receive in return for their work. Desler (2015: 417) describes compensation as all forms of payment or rewards given to employees and arising from their employment relationship. In other words, compensation is the provision of remuneration, either directly in the form of money (financial) or indirectly in the form of a reward (non-financial). In general, compensation can be interpreted as a form of payment and reward to each individual based on performance capabilities and established regulations.

\section{RESEARCH METHODS}

\subsection{Location}

This research was conducted for 6 months, from June to December 2019 at the Office of Central Statistics Agency of Kota Lubuklinggau, South Sumatra Province. Determination of the population in research according to Sugiyono (2017) is a generalized area consisting of objects or subjects that have certain qualities and characteristics determined by the researcher to be studied and then to draw conclusions from. The population in this research were all 133 partners of the Office of Central Statistics Agency in Kota Lubuklinggau.

\subsection{Types and Sources of Data}

This research is an explanatory research regarding the measurement of the readiness level of e-learning participants using a model of relationship between variables which is the result of the development of previous studies and existing theories. Explanatory research or also called explanative research is a research that examines each variable in-depth in order to obtain results regarding whether there is a relationship between the symptoms obtained from each variable. The type of data used in this study is quantitative data obtained from primary data and secondary data as supporting data for this research. Primary data is data obtained from direct sources, such as data obtained from questionnaires distrib- 
uted to and filled in by respondents, while secondary data is data obtained from literature and processed data such as previous studies, journals, and collected articles from searching on the internet relevant to the research. Source of data is from distributing questionnaires and observations. Questionnaire data collection is done by distributing a list of questions to respondents. This questionnaire is intended to obtain informative answers from respondents from the partners in Office of Central of Statistics Agency.

\subsection{Data Analysis Techniques}

Furthermore, the data and facts from the collected questionnaires will be tested using SEM data analysis techniques. The SEM analysis stage itself must go through at least five stages (Latan, 2013:42), namely: (1) model specifications; (2) model identification; (3) model estimation; (4) evaluation of the model; (5) modification or specification of the model. Basically this research consists of three stages and is run by referring to the SEM steps above and adding some basic steps outside of SEM.

\subsection{Hypothesis}

The hypothesis that underlies this research can be noted as follows.

1. $\mathrm{H} 1$ = Compensation toward motivation (influential and significant)

2. $\mathrm{H} 2$ = Compensation for performance (not influential and insignificant)

3. $\mathrm{H} 3$ = Competence towards motivation (influential and insignificant)

4. $\mathrm{H} 4$ = Competence toward performance (influential and significant)

5. H5 = Compensation and competence together have an effect on motivation

6. H6 = Motivation towards performance (influential and significant)

7. $\mathrm{H} 7$ = Compensation, competence, and motivation together have no effect

\subsection{Results}

\subsubsection{Compensation}

Compensation is anything that an employee or worker receives in any form as wages/income or compensation for services for the results/outputs given to the organization. Thus, the existence of compensation is expected the organization 
to achieve the goals of employee performance or motivation. Types of compensation for the partners of the BPS Office of Kota Lubuklinggau are presented in Table 1.

Table 1 Types of Compensation for the Partners of the BPS Office of Kota Lubuklinggau

\begin{tabular}{cll}
\hline No. & \multicolumn{1}{c}{ Compensation } & \multicolumn{1}{c}{ Information } \\
\hline 1 & Health insurance administration & There is none \\
2 & $\begin{array}{l}\text { Health insurance and work accident } \\
\text { insurance }\end{array}$ & $\begin{array}{l}\text { Provided, depending on the type } \\
\text { of survey activity being Carried } \\
\text { out }\end{array}$ \\
3 & Pension/severance pay & There is none \\
4 & Holiday allowance & There is none \\
5 & Wages for work & Provided \\
6 & Transportation costs & Provided \\
7 & Training incentives & Provided \\
\hline
\end{tabular}

Source: Central Statistic of Agency in Kota Lubuklinggau, 2019 (processed data)

The types of compensation for partners of the BPS Office of Kota Lubuklinggau appear not to be fulfilled as a whole because the types of compensation received by partners are only related to work wages, transportation costs, and training incentives, while there is no health insurance for partners. If there is, it very much depends on certain activities such as accidents while carrying out duties. Partners also do not receive pension/severance pay and holiday allowances. Lack of guaranteed compensation like this can be an obstacle to achieving optimal and maximum performance because partners are likely to have low motivation even though they have high competence. Wibowo (2015: 289) stated that the size of the compensation received can affect employee performance. Pratiwi et al. (2013) stated that in an effort to create good performance, the organization should be able to fulfil the basic needs of employees both spiritually and physically so as to stimulate high motivation and be able to improve performance. Furthermore, Rachman and Suwoko (2019) described that paying attention to employees by providing appropriate and fair compensation will improve work performance and are expected to perform well. Thus it is very necessary to fulfil the compensation for the performance carried out by the partners from the BPS Office of Kota Lubuklinggau. 


\subsubsection{Competence}

Competence is very influential on one's work performance as positive attitude will have an impact on employee performance in their field of work. Competence is the ability of employees measured on skills, knowledge, and work attitudes to do tasks assigned by the organization which will ultimately have an impact on employee performance (Wibowo, 2015:271). Azmy (2015) stated that HR competencies that are reflected in the work or performance of individuals created through their abilities (knowledge, skills, behavior, and attitudes) will be able to distinguish between good quality or mediocre HR. Competitive advantage depends on the actions of qualified individuals for the efforts to achieve organizational goals (Hofrichter and Spencer, 1996). Riwukore et al. (2019), Riwukore and Habaora (2019) stated that one of the indicators of the level of competence can be seen from the educational background of individual employees. The competency indicators of the partners of the BPS Office of Kota Lubuklinggau, South Sumatra, are presented in Table 2.

Table 2 Education Level of Partners of the BPS Office of Kota Lubuklinggau

\begin{tabular}{clcc}
\hline No. & \multicolumn{1}{c}{ Education Level } & Frequency & Percent \\
\hline 1 & Postgraduation (Strata 2/S2) & 1 & 0,75 \\
2 & Graduation (Strata 1/S1)/D4 & 71 & 53,39 \\
3 & Diploma (D3) & 6 & 4,51 \\
4 & Senior High School & 55 & 41,35 \\
5 & Junior High School & 0 & 0 \\
\hline & Total & $\mathbf{1 3 3}$ & $\mathbf{1 0 0}$ \\
\hline
\end{tabular}

Source: Central Statistic of Agency in Kota Lubuklinggau, 2019 (processed data)

Based on the educational background of the partners of the BPS Office of Kota Lubuklinggau, most partners have competencies that may be very good because they have 53,39 partners with Strata I (S1)/Diploma (D4) education and $4,51 \%$ with D3 education, and $0,75 \%$ who has a Strata II (S2) education. The results of this study can be an indicator that most partners have competence. Even so, most partners who are still considered as not having competence because they still have senior high school education/equivalent (41,35\%). Increasing competence from the training aspect is needed by partners to improve 
individual competence. Zamzam et al. (2017), Riwukore and Habaora (2018) stated that increasing competence can be done in various ways, one of which is through education and training, namely efforts to develop human resource, especially to develop human personality and intellectual abilities. An employee's competence is reflected in the education and training he has attended. In addition, the job demands of an organization/industry dynamically keep individual employees/partners abreast of developments to fulfil these demands. Purnomo et al. (2016) reported that education and training had a positive and significant influence on competence with a contribution of influence of $80,2 \%$, and education and training through competence had a positive and significant impact on performance with an impact contribution of $73,1 \%$ and the rest was the influence of other factors.

\subsubsection{Structural Equation Modelling (SEM) Analysis}

Analysis of the Structural Equation Modelling (SEM) Full Model of the four variables, namely the compensation variable, the competency variable, the motivation variable and the performance variable from work partners the Central Statistics Agency of Kota Lubuklinggau is illustrated in Figure 1 below.

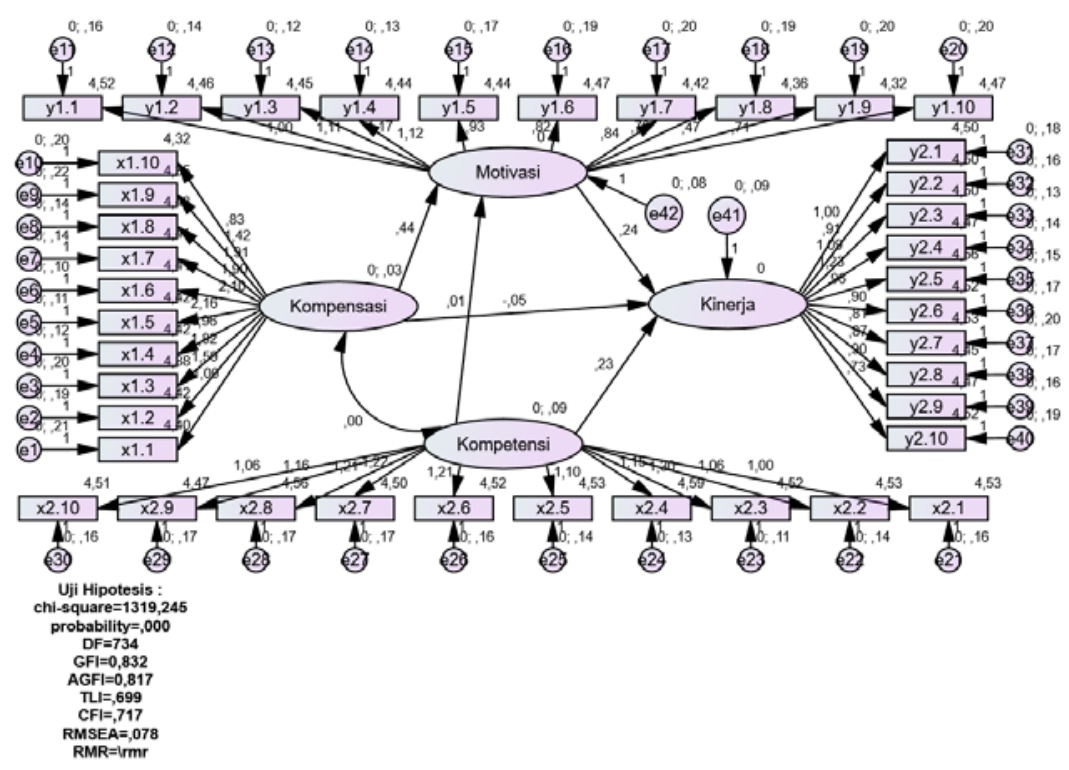

Figure 1 Confirmatory Factor Analysis (CFA) Full Model 
Figure 1 of the full model above shows that all indicators in the Full Model have a standard loading value of $>0.5$ indicating a good convergent level of validity. So, nothing drops and the results of Goodness of Fit in Table 3 show that the GOF value is fit and accepted. This shows that it is a good structural equation, and at the Critical Ratio (CR) value the model shows significance at the level $>1.96$, namely the motivation variable towards the Performance of BPS Partners in Lubuklinggau City. Therefore, that the following structural equation is obtained:

\section{Structural Equations:}

Performance $=-0,050$ Compensation $+0,234$ Competence $+0,241$ Motivation $+\mathrm{e}$

Substructural Equations:

Motivation $=0,443$ Compensation + 0,006 Competence $+\mathrm{e}$

The results of the estimation of the full model parameters in Figure 1 become a reference for testing the Hypotheses previously set, then the results of proving the Hypothesis will be the final conclusion in this research, and simultaneous testing using the Goodness of Fit criteria as listed in Table 3. Based on Figure 1, it is known that all indicators of the full model has a significant value $>0.5$. According to Wijayanto (2008), the standard factor load $\geq 0.5$ is Very Significant. Ghozali (2008) then stated that the standard loading factor $\geq 0.5$ indicates a good level of convergent validity. Thus, the dimensions and indicators in the CFA Model of exogenous constructs and endogenous constructs of variables are declared valid and significant. Furthermore, the full estimation of the simultaneous test model is carried out, namely the goodness of fit index of exogenous variables and endogenous variables, as shown in Table 3 below.

Table 3 Goodness of Fit Index Full Model

\begin{tabular}{lccl}
\hline \multicolumn{1}{c}{ Indicators } & Cut-off Value & Result & Conclusion \\
\hline $\mathrm{X}^{2}-$ Chi-square $(\mathrm{df}=5, \mathrm{p}=0,0000)$ & $<41,40$ & 1315,830 & Marginal fit \\
Sign. Probability & $\geq 0.05$ & 0,000 & Marginal fit \\
Df & $\geq 0$ & 734 & fit \\
GFI & $\geq 0.80$ & 0.832 & fit \\
AGFI & $\geq 0.80$ & 0,817 & fit \\
CFI & $\geq 0.85$ & 0,718 & Marginal fit \\
TLI/NNFI & $\geq 0.85$ & 0,701 & Marginal fit \\
NFI & $\geq 0.85$ & 0,538 & Marginal fit \\
IFI & $\geq 0.80$ & 0,724 & Marginal fit \\
RMSEA & $\leq 0.08$ & 0,077 & fit \\
RMR & $\leq 0,05$ & 0,0478 & fit \\
\hline
\end{tabular}


Based on testing in the AMOS program, the test results for each parameter are shown in Table 4.

Table 4 The Test Results for Each Parameter

\begin{tabular}{lllrrrrr}
\hline & & & Estimate & S.E. & C.R. & P & Label \\
\hline Motivation & $<---$ & Compensation &, 443 &, 203 & 2,181 &, 029 & \\
Motivation & $<---$ & Competence &, 006 &, 097 &, 063 &, 950 & \\
Performance & $<---$ & Competence &, 234 &, 108 & 2,157 &, 031 & \\
Performance & $<---$ & Motivation &, 241 &, 120 & 2,013 &, 044 & \\
Performance & $<---$ & Compensation &,- 050 &, 184 &,- 271 &, 786 & \\
\hline
\end{tabular}

\section{DISCUSSION}

Based on the results of Amos calculations, the estimated effect of compensation on the motivation of the partners of the BPS Office of Kota Lubuklinggau is 0,443 and the $C R$ value is 2,181 and the t table value $>1,96$. The results showed that there was a significant influence of compensation toward motivation. This means that the first hypothesis can be accepted because it has a positive correlation value between compensation toward motivation of the partners of the Lubuklinggau City BPS Office. Acceptance of the first hypothesis is supported by the results of data processing which shows a probability value of $0,029<0,05$ and a CR value of 2,181>1,96. The results of this study are not much different from the results of other studies that on average state that there is a relationship between compensation toward employee motivation (Aamir et al., 2012; Khan and Mufti, 2012; Rizal et al., 2014; Negash et al., 2014). If there are differences in the level of motivation when it comes to compensation, it is only influenced by differences in levels of employees in an organization (Sharma, 2013). According to Wulansari et al. (2014), if employees' perceptions of compensation increase, their motivation will increase. Thus, the Lubuklinggau City BPS Office can optimize the compensation system currently being provided. The existence of a reward model that is more in line with what partners need will result in an increase in partner motivation. Matters that need to be improved are certainties regarding health insurance, holiday allowances, and severance pay/pensions which so far have not been included in the compensation model at the 
Lubuklinggau City BPS Office. In addition, the Lubuklinggau City BPS organization can try new alternatives in the compensation system including the provision of a canteen/cafeteria for employees, communication allowances, provision of supporting partner infrastructure/accommodation, and an intensive system for achieving above average workloads.

Estimated effect of compensation for human resource of BPS Office partners in Lubuklinggau City is on the performance of $-0,050$ and CR of $-0,271$ where the $t$-table value $>1,96$. This explains that there is no positive and significant effect between compensation toward performance. The results of Amos analysis are also supported by the results of data processing which show that the probability value is $0,76>0,05$ and the $\mathrm{CR}$ value is $-0,27<1,96$. Thus the second hypothesis (there is a relationship between compensation toward performance) is rejected. The second hypothesis is rejected because there is no positive correlation between compensation toward performance of BPS partners in Lubuklinggau City. The results of this study are the same as those reported by Riyadi (2011), Mutmainah (2013), and Mundakir and Zainuri (2018) who stated that compensation does not affect employee performance. The estimation of the influencing factor is the partner's competency which is on average still low because most of the partners have a high school education background/equivalent, and all partner compensation needs have not been fulfilled. In addition, it is likely that partners work not to seek compensation because most importantly partners can have jobs. Mundakir and Zainuri (2018) stated that even though the compensation given is quite a lot, employee performance is not affected because employees already feel that the compensation is a right that they deserve. Thus, an alternative that can be recommended from the results of this study is an intensive system setting based on average workloads in order to affect the improvement of the quality and quantity of performance.

The estimated influence of competence toward motivation is 0,006 and CR 0,063 and the $t$ table value $>1,96$. This means that there is a positive but insignificant influence between competence toward the motivation of work partners of the office of BPS, Lubuklinggau City. The results of this estimate are also in accordance with the results of data processing with a probability value of $0,950>0.05$ and a CR value of $0,063<1,96$. Thus the third hypothesis is accepted because there is a positive correlation between the competence toward 
motivation of the partners of the office of BPS Lubuklinggau City. The results of this study are in accordance with those reported by Dwiyanti et al. (2019) who stated that competence has a real and significant effect on work motivation. This situation is closely related to the competence of some partners of the Lubuklinggau City BPS Office, which are more dominated by partners with diploma, bachelor, and master backgrounds so that they can influence other partners in the organization. This argument is in accordance with Wibowo (2015) stating that there are two main factors affecting motivation, namely (1) employees, consisting of abilities, knowledge, character and characteristics, emotions, moods, beliefs and values; and (2) work, including the physical environment, assigned tasks, organizational approaches to superior recognition and recognition, supervision, guidance, and organizational culture.

Estimation of the influence of the competence of human resource partners of the BPS Office of the City of Lubuklinggau toward performance is 0,234 and the value of $\mathrm{CR}$ is 2,157 , where the $\mathrm{t}$-table value $>1,96$. The results showed that there was a positive and significant influence between competence toward performance. The condition of this research is supported by a probability value of $0,031<0,05$ and a CR value of 2,157 > 1,96. Thus, the fourth hypothesis is accepted because there is a positive correlation between the competence toward performance of the partners of the BPS office of Lubuklinggau City. The acceptance of this hypothesis is in accordance with the results of research reported by Nirmalawati (2009) and Valentina et al. (2018), which stated that there is a significant positive relationship between competence toward performance with a contribution percentage of $>73 \%$. The competence referred to will affect the performance of partners, the level of performance has increased in each period, and the performance of the organization continues to improve. Riwukore (2010) stated that competence is a special attribute such as knowledge and skills that are used to show the ability to perform at the job being done. Fathurrochman (2017) described that competence is the ability to carry out work in accordance with the education and or training that has been experienced to achieve maximum performance.

Based on the results of Amos calculations, the estimated effect of compensation and competence of BPS Office of Lubuklinggau City partners toward motivation is 0,241 and $\mathrm{CR}$ is 2,013 where the t-table value is $>1,96$. That 
means, there is a positive and significant influence between compensation and competence to motivation. Thus the fifth hypothesis is accepted. This is reinforced by the results of data processing which show a probability value of 0,044 $<0,05$ and a CR value of $2,013>1,96$. The results of the study are the same as those reported by Ngatemin and Arumwanti (2013) in which there is a positive and significant relationship between compensation and competence variables toward work motivation, meaning that these two variables are very decisive in increasing the work motivation of partners of the BPS Office in Lubuklinggau City. The magnitude of the influence of compensation and competence can be used as a guide as an effort to increase the work motivation of partners. Wulansari et al. (2014) stated that if the compensation is good, it will have a positive impact on employee work motivation, and according to Komara (2019), if there is good individual competence, it is hoped that a person's work motivation can increase even better in carrying out his job.

Estimation of the effect of work motivation on partner performance results in the criteria for the value of goodness of index (fit value) of only 5. That is, there is no positive and significant influence between work motivation on partner performance. The results of this study mean that if the work motivation of the partners is increased or not increased, it will not affect the performance of the partners. The results of this study are not in accordance with those reported by Azar and Shafighi (2013) and Agusta (2013) that there is a positive and significant influence between work motivation on employee performance. The factor that may influence is compensation that has not been based on performance because every partner who works well still do not guarantee them to get higher compensation. In addition, partners consider that they only want to get a job, and competencies such as educational background are not yet a prerequisite for differentiating compensation. Luhur (2014) stated that this negative employee perception causes no influence of motivation on employee performance (partners). Thus, it is necessary to do competency-based human resource management and compensation to increase motivation for performance results.

Estimating the effect of compensation, competence and motivation together on the work partner performance of the Lubuklinggau City BPS Office, the Goodness of Index criteria obtained only fit 5 criteria and did not fulfil at least 7 criteria. The results of this study explain that there is no positive and 
significant effect between compensation, competence, and motivation together on the work partner performance of the Office of the Central Bureau of Statistics, Lubuklinggau City. The results of this study are in line with those reported by Riyadi (2011), Mutmainah (2013), Luhur (2014), and Meutia et al. (2016) stating that partially or jointly there is no real and negative effect on the relationship between compensation, competence, and motivation on employee (partner) performance. The influencing factor is compensation that has not satisfied partners, as most partners have competencies with sufficient educational background and perhaps minimal experience, and there is no difference in the quality and quantity of performance achievement. Mundakir and Zainuri (2018) stated that the size of the compensation received has no effect on performance because employees work not only to seek compensation. Valentina et al. (2018) stated that there are more dominant factors such as leadership style, work environment, organizational culture, job satisfaction, and so on which have a higher determination value than compensation, competence, and motivation to improve performance. Luhur (2014) reported that $92.4 \%$ of performance achievement is influenced by other factors besides motivation, compensation and competence.

\section{CONCLUSION}

Based on the results of the analysis and statistical testing of motivation research data as an intervening variable on the performance of the partners of the Central Bureau of Statistics, Lubuklinggau City, South Sumatra, it can be concluded that (1) aspects of compensation and competence have not become a serious concern of the Central Bureau of Statistics for its partners; (2) there is a positive and significant relationship between compensation toward motivation, competence toward performance, compensation and competence together toward performance. On the other hand, it appears that there is no positive and significant effect between compensation toward performance, motivation toward performance, compensation-competence-motivation together toward performance, and also there is a positive but not significant influence between competence toward motivation. The results of this study indicate that there needs to be an improvement in competence and compensation from the Office of the Central 
Bureau of Statistics of Lubuklinggau City to its partners to affect the increase in motivation to produce good and maximum performance. Compensation improvement can be done by understanding individual motivational characteristics which are formed from the need for safety, respect, autonomy, self-actualization, and socialization.

\section{REFERENCES}

Aamir, A., Jehanzeb, K., Rasheed, A., \& Malik, O. M. (2012). Compensation methods and employees motivation (with reference to employees of $\mathrm{Na}$ tional Commercial Bank Riyadh). International Journal of Human Resource Studies, 2(2), 221-230.

Afifuddin. (2017). Manajemen Sumber Daya Manusia. Bandung: Pustaka Setia Press.

Almasri, M. N. (2016). Manajemen sumber daya manusia: Implementasi dalam pendidikan Islam. Kutubkhanah: Jurnal Penelitian Sosial Keagamaan, 19(2), 133-151.

Armstrong, M. (2014). Human resource management. New York (USA): Prentice Hall.

Azmy, A. (2015). Pengembangan kompetensi sumber daya manusia untuk mencapai career ready profesional di Universitas Tanre Abeng. Binus Business Review, 6(2), 220-232.

Busro, M. (2018). Teori-teori manajemen sumber daya manusia. Jakarta: Prenada Media Press.

Danila, \& Riwukore, J. R. (2019). Pengaruh kompetensi dan motivasi terhadap kinerja pegawai di Dinas Pekerjaan Umum Bina Marga Provinsi Sumatera Selatan. Jurnal Ecoment Global, 4(2), 39-51.

Desler, G. (2015). Manajemen sumber daya manusia. Jakarta: Salemba Empat Press.

Dwiyanti, N. K., Heryanda, K. K., \& Susila, G. P. (2019). Pengaruh kompetensi dan motivasi kerja terhadap kinerja karyawan. BISMA: Jurnal Manajemen, 5(2), 121-130.

Fathurrochman, I. (2017). Pengembangan kompetensi pegawai Aparatur Sipil Negara (ASN) Sekolah Tinggi Agama Islam Negeri (STAIN) Curup melalui 
metode pendidikan dan pelatihan. Jurnal Manajer Pendidikan, 11(21), 120129.

Fauziah, S., Sunuharsyo, B. S., \& Utami, H. N. (2016). Pengaruh kompensasi langsung dan kompensasi tidak langsung terhadap motivasi kerja karyawan dan kinerja karyawan. Jurnal Administrasi Bisnis, 37(1), 178-187.

Habaora, F. (2015). Populasi opini penyalahgunaan kekuasaan. Yogyakarta: Deepublish Press.

Habaora, F. (2020). Strategi pengembangan sapi Bali berbasis agroekosistem di Pulau Timor (Disertasi). Bogor (ID): Sekolah Pascasarjana, Institut Pertanian Bogor.

Handoko, T. H. (2011). Manajemen personalia dan sumber daya manusia. Yogyakarta: Badan Penelitian Fakultas Ekonomi (BPFE) Press.

Hartatik, I. P. (2014). Buku praktis mengembangkan SDM. Yogyakarta: Laksana Press.

Hasibuan, H. M. (2003). Organisasi dan motivasi: dasar peningkatan produktivitas. Jakarta (ID): Bumi Aksara Press.

Hasibuan, M. S. (2014). Manajemen sumber daya manusia. Jakarta, Indonesia: Bumi Aksara Press.

Hofrichter, D. A. \& Spencer, L. M. (1996). Competencies: The rigth foundation for effective human resource management. Compensation and Benefits Review, 28(6), 21-24.

Irham, F. (2014). Manajemen teori, kasus dan solusi. Bandung: Alfabeta Press. Khan, W. \& Mufti, E. O. (2012). Effect of compensation on motivating employees in Public and Private Banks of Peshawar (BOK and UBL). Journal of Basic and Applied Scientific Research, 2(5), 4616-4623.

Komara, E. (2019). Kompetensi profesional pegawai ASN (Aparatur Sipil Negara) di Indonesia. Mimbar Pendidikan: Jurnal Indonesia untuk Kajian Pendidikan, 4(1), 73-84.

Latan, H. (2013). Model persamaan struktural: Teori implementasi Amos 21.0. Bandung: Alfabeta Press.

Luhur, R. Y. (2014). Pengaruh kepemimpinan, motivasi kerja dan lingkungan kerja terhadap kinerja karyawan pada Biro Pengawasan dan Pemeriksaan PT Bank Panin Tbk. Operations Excellence: Journal of Applied Industrial Engineering, 6(3), 327-344. 
Luthans. (1997). Organizational Behavior (Sevent Edition ed.). Singapore: McGraw-Hill International Edition Printed .

Mundakir, \& Zainuri. (2018). Pengaruh kompensasi dan motivasi terhadap kinerja Pegawai Negeri Sipil dengan kepuasan kerja sebagai variabel intervening. Business Management Analysis Journal, 1(1), 37-48.

Mutmainah, H. (2013). Pengaruh kompensasi, pelatihan, dan peran supervisor terhadap kinerja yang dimediasi oleh kepuasan kerja pada karyawan Paguyuban Batik Laweyan Surakarta. Jurnal Graduasi, 29(1), 1-20.

Negash, R., Zewude, S., \& Megersa, R. (2014). The effect of compensation on employees motivation: In Jimma University Academic Staff. Basic Research of Business Management and Accounts, 3(2), 17-27.

Ngatemin, \& Arumwanti, W. (2013). Pengaruh kompetensi dan kompensasi terhadap motivasi kerja karyawan hotel di Kabupaten Karo Provinsi Sumatera Utara. Jurnal Riset Akuntansi dan Bisnis, 13(1), 80-92.

Nirmalawati. (2009). Hubungan antara kapabilitas kepemimpinan, kompetensi dosen, komitmen dosen, dan akuntabilitas lembaga dengan kinerja lembaga dalam pelaksanaan penjaminan mutu pada Universitas Negeri di Jawa Timur. Jurnal Pendidikan dan Pembelajaran, 16(2), 116-124.

Nuryani. (2018). Kompetensi profesional Guru Bahasa dan Sastra Indonesia. Jurnal Bahastra, XXXVIII(1), 2548-4583.

Palan. (2003). Competency management a practitioner guide (Terjemahan Octa Media Jalal ed.). Jakarta: Penerbit PPM 2007.

Pratiwi, A., Kuswinarno, M., \& Faidal. (2013). Pengaruh kompensasi terhadap kinerja karyawan pada PT. Pos Indonesia (Persero) Kantor Cabang Bangkalan. Jurnal Program Studi Manajemen Universitas Trunojoyo Madura, 1(1), 112.

Purnomo, D., Sudana, I. P., \& Mananda, I. G. (2016). Pengaruh pendidikan dan pelatihan terhadap kompetensi serta dampaknya pada kinerja Pramuwisata Bali. Jurnal IPTA: Industri Perjalanan Wisata, 4(2), 52-57.

Rachman, A. N. \& Suwoko. (2019). Effect of compensation on employee performance PT. Mega Finance Samarinda. Borneo Student Research, 1(1), 63-68.

Riwukore, J. R. (2010). Pengaruh Kepemimpinan Transformasional, Kompetensi dan Motivasi terhadap Komitmen dan Kinerja Karyawan di Sekretariat 
Pemerintah Daerah Kota Kupang Nusa Tenggara Timur [Disertasi]. Surabaya: Program Doktor Ilmu Ekonomi, Program Pascasarjana, Universitas 17 Agustus 1945.

Riwukore, J. R. \& Habaora, F. (2018). Sistem Produksi Sapi Potong. Jogjakarta: Deepublish.

Riwukore, J. R. \& Habaora, F. (2019). Expenditure display of education cost on households in Kota Kupang and the policy of masterplan. International Journal of Innovative Science and Research Technology, 4(7), 93-99.

Riwukore, J. R. \& Habaora, F. (2019). Perception of farmers on the performance of extensionist in the pasture agroecosystem of Timor Tengah Utara District. Asian Journal of Agricultural Extension, Economics \& Sociology, 29(2), 1-10. doi:10.9734/AJAEES/2019/45539.

Riwukore, J. R., Susanto, Y., Manafe, H., Habaora, F., \& Miramangngi, S. (2019). Analisis postur APBD dan APBD Pendidikan Kota Kupang. Jurnal Penelitian Kebijakan Pendidikan, 12(2), 182-192.

Riyadi, S. (2011). Pengaruh kompensasi finansial, gaya kepemimpinan, dan motivasi kerja terhadap kinerja karyawan pada perusahaan manufaktur di Jawa Timur. Jurnal Manajemen dan Kewirausahaan, 13(1), 40-45.

Rizal, M., Idrus, M. S., \& Djumahir, M. R. (2014). Effect of compensation on motivation, organizational commitment and employee performance (Studies at Local Revenue Management in Kendari City). International Journal of Business and Management Invention, 3(2), 64-79.

Sari, E. P. \& Touana, H. (2017). Komponen kompensasi pekerja level staf berstatus pekerja waktu tak tertentu pada PT Pertamina Patra Niaga Jakarta Selatan. Jurnal Administrasi Kantor, 5(1), 69-82.

Sedarmayanti. (2017). Sumber Daya Manusia dan Produktivitas Kerja. Bandung: CV. Mandar Maju.

Sharma, R. (2013). The impact of various components of compesation on the motivation level of employees - a comparative study of selected Indian Public and Private Sector Banks. International Journal of Application or Innovation in Engineering and Management, 2(7), 511-516.

Sugiyono. (2017). Metode Penulisan Kuantitatif, Kualitatif, dan Kombinasi (mixed methods). Bandung: Alfa Beta Press. 
Susiawan, S. \& Muhid, A. (2015). Kepemimpinan transformasional, kepuasan kerja dan komitmen organisasi. PERSONA: Jurnal Psikologi Indonesia, 4(3), 304-313.

Sutrisno, E. (2017). Manajemen Sumber Daya Manusia. Jakarta: Prenadamedia Group Press.

Sutrisno, S. (2013). Pengaruh disiplin kerja dan motivasi kerja terhadap kinerja Pegawai Negeri Sipil (Studi di Kantor Dinas Sosial Provinsi Jawa Tengah). Jurnal Ilmiah Dinamika Ekonomi dan Bisnis, 1(1), 1-15.

Tsani F. A. (2013). Pengaruh kompetensi, penempatan kerja dan motivasi terhadap kinerja pegawai Sekretariat Jenderal Kementerian Luar Negeri. MIX: Jurnal Ilmiah Manajemen, 3(1), 12-23.

Valentina, R., Maisyaroh, \& Kusumaningrum, D. E. (2018). Hubungan kompetensi dan motivasi kerja dengan kinerja Tenaga Administrasi Sekolah. Jurnal Administrasi dan Manajemen Pendidikan, 1(1), 79-86.

Wibowo. (2015). Manajemen Kinerja. Edisi Kelima. Jakarta: PT Raja Grafindo Press.

Wijayanto, A., Hubeis, H. M., Affandi, M. J., \& Hermawan, A. (2011). Faktorfaktor yang mempengaruhi kompetensi kerja karyawan. Manajemen IKM, 6(2), 81-87.

Wulansari, P., Damanik, A. H., \& Prasetio, A. P. (2014). Pengaruh kompensasi terhadap motivasi karyawan di Departemen Sumber Daya Manusia PLN Kantor Distribusi Jawa Barat dan Banten. Jurnal Manajemen Indonesia, 14(2), 163-171.

Yani, M. (2012). Manajemen Sumber Daya Manusia. Jakarta: Mitra Wacana Media Press.

Zamzam, F., Riwukore, J. R., \& Harun. (2017). Model pendampingan keahlian untuk peningkatan kapasitas pembahasan rencana anggaran pendapatan dan belanja daerah. Jurnal Abdimas Mandiri, 1(1), 31-36.

Zamzam, F., Satria, C., \& Riwukore, J. R. (2018). Meningkatkan Motivasi Berafiliasi Pegawai Sekretariat Dewan Perwakilan Rakyat Daerah Kabupaten se-Sumatera Selatan. Jurnal Ecoment Global, 3(2), 208-222. 
Review of Management and Entrepreneurship

Volume 05, Number 02, October 2021 